\title{
UNIVERSO MORAL DE JOVENS INTERNOS DA FEBEM
}

\author{
NATÁLIA FELIX DE CARVALHO NOGUCHI \\ Mestre em Psicologia Escolar e do Desenvolvimento Humano \\ pelo Instituto de Psicologia da Universidade de São Paulo \\ nataliafcnoguchi@hotmail.com
}

YVES DE LA TAILLE

Instituto de Psicologia da Universidade de São Paulo

yves@originet.com.br

\begin{abstract}
RESUMO
Neste estudo, apresentamos elementos do universo moral de jovens internos da Fundação do Bem-Estar do Menor do Estado de São Paulo. Entrevistamos 14 sujeitos sobre o tema do 'Seguro', uma forma de organização criada pelos próprios jovens internos, que está baseada em regras precisas cuja desobediência implica a exclusão do transgressor. Procuramos verificar as formas de legitimação da referida organização, e os valores morais que a sustentam. As categorias de análise dos dados foram: autonomia/heteronomia, virtudes e personalidade moral. Os dados apontam para o predomínio de formas heteronômicas de legitimação das regras, para a valorização de certos traços de caráter (virtudes) como a 'firmeza', a 'virilidade', a 'coragem' e para a franca desvalorização de seus contrários (fraqueza, homossexualidade, medo). Os dados também apontam para a construção de uma identidade que inclui valores do chamado 'mundo do crime' e que se opõe claramente ao 'mundão', que inclui as pessoas que não são os 'malandros'. ADOLESCENTES - FEBEM - VALORES - IDENTIDADE
\end{abstract}

\section{ABSTRACT}

MORAL UNIVERSE OF JUVENILE OFFENDERS IN INTERNMENT AT THE SÃO PAULO STATE FUNDAÇÃO DO BEM-ESTAR DO MENOR. This study describes the moral universe of juvenile offenders in internment at the São Paulo State Fundação do Bem-Estar do Menor. Fourteen male adolescents were interviewed on the subject of 'Seguro', i.e., an organisational code created by themselves, involving a precise set of rules whose inobservance implies the exclusion of the transgressor. We aimed at investigating this code legitimacy, as well as the moral values supporting it. The categories devised for data analysis were: autonomy/heteronomy; virtues, and moral self. The data show a prominence of heteronomous forms of legitimation of rules; the valorization of certain character traits (virtues) such as strength, virility, and courage, and the sharp devaluation of their opposites: weakness, homosexuality, and fear. Our results also point out to the construction of an identity which encompasses values in the so-called "crime world", clearly opposed to those cultivated in the "mundão"- literally, big world, i.e., society -, regarding the people who are not "malandros" - a positive word for bandit, used by the respondents.

ADOLESCENTS - FEBEM - VALUES - IDENTITY 
Os estudos das Unidades de Internação da Fundação do Bem-Estar do Menor do Estado de São Paulo - Febem/SP - evidenciam um funcionamento, cada vez mais conhecido pela população em geral: a existência de uma organização, entre os adolescentes internos, muito semelhante à do sistema prisional. Nos últimos tempos, diversas pesquisas (Aun, 2005; Teixeira, 2002; Vicentin, 2005; Sarti, 2004) interpretam esse fenômeno, segundo diferentes olhares, mas com pontos em comum: a violência na Febem está aumentando, os adolescentes têm uma organização interna cada vez mais estruturada e com cada vez menor possibilidade de intervenção de funcionários; o sistema prisional invadiu as unidades chamadas socioeducativas. Para Vicentin (2005), "não é desprezível a hipótese [...] de que as rixas e os jovens no 'seguro' estão aumentando, produzindo-se como conseqüência de estarem sendo empurrados para uma lógica prisional" (p. I 52).

Todavia, nosso intento não será, aqui, o de avaliar as semelhanças e relações entre sistemas de organização dos jovens internos com a chamada lógica prisional, mas sim o de procurar jogar luzes sobre o que tais sistemas podem nos ensinar sobre o universo de valores morais desses jovens e, por conseguinte, trazer dados que possam inspirar políticas educacionais minimamente eficazes para a inserção dessa população no convívio social mais amplo. Nesse caso, não basta conhecer as diversas formas de organização promovidas pelos jovens internos: é preciso que eles próprios falem delas, se posicionem a respeito da razão de ser das regras e de sua legitimidade.

Ao fazer isto, aliás, estaremos retomando alguns dos passos do precioso estudo de Jean Piaget sobre as 'regras do jogo'. Como se sabe, Piaget (1992) inicia seu estudo sobre o juízo moral das crianças questionando-as acerca da interpretação de regras de jogos infantis, regras estas não atribuíveis aos mandamentos adultos, mas sim às criações dos jogadores. Embora as regras dos jogos não sejam elas mesmas morais, tal estudo permitiu a Piaget tecer hipóteses sobre a moralidade infantil, porque traços de heteronomia e autonomia - conceitos centrais para a Filosofia e para a Psicologia Morais - podem ser encontrados em toda e qualquer relação, para regras de todo tipo. A vantagem que o psicólogo suíço via nesse método era a de penetrar um universo tipicamente infantil e, sobretudo, a de estudar os juízos decorrentes de atividades praticadas por seus sujeitos. Quando ele estudou a moral propriamente dita, mudou de método e empregou dilemas morais. Ora, a maioria dos estu- 
Universo moral...

dos da Psicologia Moral, com destaque para Lawrence Kohlberg (|98|), emprestou de Piaget apenas o método dos dilemas, ou seja, o instrumento que coloca aos sujeitos situações morais precisas, mas pelas quais, muito provavelmente, os sujeitos nunca passaram. A riqueza desse método é, sem dúvida, a de apresentar uma situação na qual elementos morais essenciais estão presentes (pense-se no famoso dilema de Heinz, elaborado por Kohlberg). Em compensação, os limites do método, que Piaget já apontava, são justamente não corresponder a práticas sociais efetivamente vividas e de não garantir, portanto, o desvendamento de juízos cujas raízes encontram-se nas experiências cotidianas. Ora, pretendemos, neste estudo, fazer os jovens da Febem revelarem que regras legitimam e por quê. Não se encontrará, portanto, em nosso texto, o juízo de nossos sujeitos sobre dilemas morais clássicos ou outras situaçõesproblema, nem um diagnóstico do nível de seu desenvolvimento moral, mas depoimentos exclusivamente relacionados às suas vidas, na instituição em que foram colocados pelos poderes públicos.

fenômeno organizacional que escolhemos é o Seguro. Em poucas palavras, trata-se de uma prática de exclusão de jovens internos do convívio com os demais. Como veremos a seguir, ela é uma organização criada pela própria coletividade dos jovens, repleta de regras de convívio, de hierarquias e de sanções. Mas, antes de mais nada, devemos nos perguntar se, ao estudar os juízos que nossos sujeitos tecem a respeito de tais regras, estaremos, de fato, estudando o universo de seus valores morais. Todo problema reside em conceituar o que seja moral.

Se definirmos moral como um conjunto de costumes legitimados para o convívio social, ao estudar o Seguro estaremos, é claro, penetrando numa parte do universo moral de nossos sujeitos. Tal definição é formal, pois não implica escolher um conteúdo, como a generosidade, por exemplo. Todavia, se, com Kohlberg ( 198 I) e Turiel (1993), elegemos a justiça como a virtude incontornável de todo sistema moral, muitas das regras de convívio dos jovens não merecerão o nome de moral, mas de convenções coletivas. Em compensação, se elegermos, para saber o que é considerado moral por um indivíduo, o critério psicológico do sentimento do dever, ou seja, o sentimento de obrigatoriedade que preside a legitimação e o respeito pelas regras ou o valor absoluto de certos traços de caráter, cada vez que verificarmos que nossos sujeitos consideram determinadas condutas e atitudes como necessárias, 
poderemos afirmar que estamos desvendando um aspecto de seu universo moral. Essa última alternativa também é formal, pois toda regra tida como objeto de uma obediência obrigatória poderá ser considerada, para o sujeito estudado, moral. É claro que estamos falando de uma obediência livremente consentida: se ela decorrer apenas do medo da sanção, não se trata de moral, mas de prudência.

Temos, portanto, três critérios: um sociológico (costumes de convívio de fato existente), um filosófico (eleger um conteúdo), outro psicológico (o sentimento de obrigatoriedade). Ficaremos com o terceiro, o critério psicológico, e procuraremos, nas falas de nossos sujeitos, referências à obediência estrita a determinadas regras e ao valor praticamente absoluto de certos traços de caráter.

Três são as categorias por intermédio das quais analisaremos os depoimentos recolhidos: "heteronomia/autonomia", "virtudes", "personalidade moral”. Cabe, antes, explicitar cada uma delas e justificar sua relevância.

\section{HETERONOMIA/AUTONOMIA}

Heteronomia e autonomia são temas clássicos dos estudos sobre moralidade. São pelo menos duas as formas de interpretar esses conceitos. Uma forma refere-se à questão da liberdade, outra, à questão da autoridade.

Quanto à liberdade, é considerado estar em posição de heteronomia quem está coagido, seja por uma força externa, seja por uma força interna. Por força externa, entende-se alguma forma de poder à qual o indivíduo está submetido, poder que o ameaça com retaliação, se não for obedecido. Por exemplo, alguém obrigado a ir à guerra sob pena de, em caso de recusa, ser fuzilado pelas Forças Armadas. E por força interna, entende-se alguma função psicológica que impede o indivíduo de guiar suas ações por intermédio de suas faculdades intelectuais. Por exemplo, um surto psicótico que, momentaneamente, aniquila o poder de decisão da razão. Outro exemplo: uma força afetiva inconsciente que leva a pessoa, à sua revelia, a agir de determinadas maneiras. Tanto em caso de força externa quanto de força interna, não há liberdade. Se houvesse, falar-se-ia em posição de autonomia. No que tange à liberdade, pode-se dizer, com Kant (1994), que ela é condição necessária para que uma ação possa ser considerada moral. Aceita essa condição, a heteronomia enten- 
Universo moral...

dida como não liberdade não configura certo tipo de moralidade, mas sua radical ausência. Assumiremos, aqui, essa posição.

Há, no entanto, outra definição de heteronomia, propriamente moral, pois caracteriza um tipo de moralidade. É aquela referente à dimensão da autoridade. É considerado moralmente heterônomo quem, para legitimar determinadas regras e princípios morais, refere-se a alguma fonte exterior à sua consciência, fonte esta cujo valor é suficiente para sustentar tal legitimação. É o caso, por exemplo, dos sistemas morais oriundos da religião cristã: a palavra de Deus é a referência primeira para abalizar deveres morais. Mas outras podem ser as fontes externas e transcendentes: entre elas, os adultos (Piaget, 1992); o "ser coletivo" (Durkheim, 1974), o prestígio social de certos agentes institucionais (Milgram, 1974), o grupo ao qual se pertence (Kohlberg, 1981). A autonomia moral se caracteriza pela não-referência a figuras de autoridade para a legitimação da moral.

Os conceitos de heteronomia e autonomia são bastante empregados por teorias da Psicologia Moral, notadamente aquelas que estudam o desenvolvimento do juízo moral. Com efeito, para Piaget, depois de uma fase de anomia, o primeiro estágio do desenvolvimento é o da heteronomia, sendo superado, posteriormente, pelo estágio da autonomia. Piaget contentou-se em verificar a presença de alguns traços de autonomia para sustentar tal hipótese, mas nunca afirmou ser um adolescente plenamente autônomo (Piaget, 1977). Coube a Kohlberg (|98|), demonstrar que a conquista da autonomia é, de fato, muito rara, permanecendo a maioria das pessoas referenciadas a fontes externas de legitimação de seus sistemas morais.

Dada a importância dos referidos conceitos para o estudo da moralidade, não poderíamos deixar de procurar verificar se os jovens que entrevistamos encontram-se numa posição mais heterônoma ou mais autônoma (se empregamos o quantificador "mais", é que não estamos visando situar nossos sujeitos em estágios precisos de desenvolvimento, mas, sim, desvendar elementos de seus juízos morais, elementos esses que podem apontar mais para uma posição do que para outra). Mais ainda, uma vez que o Seguro corresponde a uma organização social criada pelos próprios internos, é lícito nos perguntarmos se são relações de cooperação estabelecidas entre sujeitos autônomos que presidem a sua constituição ou se, pelo contrário, tal organização é concebida como imposta por alguma fonte exterior a seus membros. 
Isto posto, devemos agora lembrar algumas categorias por intermédio das quais poderemos avaliar a presença de posições heterônomas ou autônomas. A primeira delas é a "presença ou ausência de justificativas" para a razão de ser das regras. Se houver tal justificativa, pode-se falar em autonomia, do contrário, em heteronomia. A segunda categoria refere-se "ao primado da regra ou ao primado do princípio moral", de onde ela decorre. Se encontrarmos essencialmente regras apresentadas e interpretadas "ao pé da letra", teremos um indício de posição heterônoma; se encontrarmos a explicitação de princípios (o "espírito" da regra) poderemos falar em posição autônoma (Piaget, 1992). A terceira categoria refere-se à responsabilidade. Se esta for pensada como "objetiva" (primazia da avaliação do ato e de suas conseqüências em detrimento da intenção que o preside), poderemos falar em heteronomia. Em compensação, se verificarmos que a valorização da responsabilidade é "subjetiva" (maior valor dado à intenção), poderemos falar em autonomia. A quarta categoria que empregaremos diz respeito ao processo de construção e legitimação das regras: se tal processo for o da "cooperação", será sinal de autonomia; se for de "coação", de heteronomia (Piaget, 1992). A quinta categoria será a das punições. Se forem valorizadas as sanções expiatórias, será sinal de heteronomia, se forem as sanções por reciprocidade, será sinal de autonomia (Piaget, 1992).

\section{VIRTUDES}

O tema das virtudes é clássico na Filosofia Moral. Elas não dizem diretamente respeito às ações morais, mas aos traços de caráter desejáveis para que elas sejam realizadas. Mais ainda, em certos sistemas éticos, como o de Aristóteles, algumas são evocadas como condição necessária para o alcance e usufruto da "vida boa" (Aristote, 1965).

Note-se que a referência a virtudes pouco se encontra na Filosofia e Psicologia Morais do século XX. A influência kantiana explica em parte essa ausência. Para ele, a moral não é somatória de virtudes, ela é o respeito a imperativos categóricos cujo eixo central consiste em agir de forma a tratar outrem nunca apenas como meio, mas sempre como fim em si mesmo. Com Tugendhat (1998), podemos dizer que, para o filósofo alemão, a moral implica a virtude, o próprio ser moral, e não um leque de disposições de caráter. 
Universo moral...

Tais disposições são necessárias ao cumprimento dos deveres - Kant defende o auto-aperfeiçoamento como condição necessária da moralidade -, mas não os definem. Cada virtude somente será boa se a serviço dos imperativos categóricos. A Psicologia Moral tem seguido essa linha de raciocínio. Como Kant, Durkheim também fala na virtude de ser moral, e não em várias virtudes. Caberá a Kohlberg ( 1981 ) afirmar claramente que o ser humano não é um "saco de virtudes", mas sim um ser que desenvolve seus juízos morais em torno de uma virtude só, sempre boa, e que determina o valor das demais: a justiça. Quanto a Piaget, embora não se posicione claramente sobre a questão, verifica-se que quando pesquisa virtudes como fidelidade e generosidade, não são tais virtudes em si mesmas que o interessam, mas sim os elementos de respeito unilateral ou mútuo que determinam, para os sujeitos, o seu valor.

Falta apontar que o tema das virtudes, entendendo-se que cada virtude tem um valor irredutível às outras ou a uma em particular, voltou a interessar filósofos e psicólogos desde o final do século passado. Carol Gilligan (1982), ao avaliar que pensar a moral exclusivamente a partir dos princípios de justiça leva a privilegiar posturas masculinas, cunhou a expressão "ética do cuidado" para caracterizar um aspecto essencial da moral feminina. Ora, ao fazê-lo, não deixou de colocar o conceito de virtude no plural: não haveria uma só, mas pelo menos duas. Na Filosofia, podemos destacar, entre outros, Maclntyre (198I), Tugendhat (1998), Flanagan (1996) e Comte-Sponville (1995), autores que voltam ao tema das virtudes. Cada qual à sua maneira afirma que o desprezo pelo tema tem empobrecido as reflexões sobre a moralidade. Não afirmam, portanto, que devemos voltar à tese de um "saco de virtudes": afirmam que, para compreender as ações morais dos homens, qualidades como a coragem, a generosidade, a lealdade, a solidariedade, a humildade etc. são incontornáveis (La Taille, 2000).

É nessa última perspectiva que nos colocamos. Para nós, o tema das virtudes é, de fato, incontornável para a moralidade. Primeiramente, sabe-se que algumas comparecem como fatores importantes no desenvolvimento moral (Eisenberg, 1979; Hoffman; 1978; La Taille, 2006). Em segundo lugar, como vamos frisá-lo, quando falarmos de "personalidade moral", uma vez que estas se associam a qualidades do eu e que tais qualidades dizem respeito à fonte energética da ação moral, o tema das virtudes interessa aos estudos da dimensão afetiva da moralidade. Em terceiro e último lugar, as observações corriquei- 
ras demonstram que os seres humanos, em geral, evocam-nas quando refletem sobre a moral. Aliás, é interessante notar a repercussão que textos sobre as virtudes têm tido ultimamente: por exemplo, O pequeno tratado das grandes virtudes, de Comte-Sponville (1995), e O livro das virtudes, de Bennet (1995). Interessante também notar o quanto as propagandas políticas costumam colocar nas telas candidatos agraciados por diversas qualidades de caráter: corajoso, honesto, responsável, humilde etc. Em suma, cremos que, para entender o universo moral dos seres humanos, é necessário e rico pesquisar como avaliam e julgam diversas virtudes. É o que fizemos com os sujeitos da pesquisa. Eles espontaneamente se remetem a diversos traços de caráter que consideram do mais alto valor e necessários ao convívio social. Pensamos que seria um grave erro teórico e uma grave lacuna empírica não contemplar tais referências para descrever o universo moral no qual se movem.

\section{PERSONALIDADE MORAL}

Acabamos de ver que as virtudes se relacionam com traços de caráter passíveis de serem contemplados por alguns sistemas morais. Elas remetem, portanto, ao eu. Ora, existe uma abordagem teórica que faz menção ao eu para explicar a fonte motivacional da ação moral. Tal abordagem responde pelo nome de "personalidade moral" (Colby, Damon, 1993; Blasi, I995; Puig, 1998) ou "personalidade ética" (La Taille, 2006a). As teses de base dessa abordagem podem ser resumidas como segue.

O eu, ou self, é considerado como um conjunto de representações de si. Tais representações são sempre valores. Ou seja, a pessoa vê a si própria como valor e busca identificar-se com valores por ela considerados positivos. conjunto de representações de si é concebido como um sistema, no qual alguns valores são centrais - portanto de maior importância para a pessoa - e outros periféricos - de menor importância. A manutenção dos valores centrais gera um força motivacional, pois a pessoa deseja agir de forma condizente com eles. Logo, se os valores chamados centrais forem, eles mesmos, morais (ser justo, ser honesto etc.), haverá maior probabilidade de a ação moral ser seguida. Numa pesquisa realizada com indivíduos de vida moral exemplar, Colby e Damon verificaram que, de fato, para eles, ser moral e ser eles mesmos era uma só e mesma coisa. Escrevem os autores que 
Universo moral...

...quando há unidade entre eu e moralidade, juízo e conduta são diretamente e previsivelmente relacionados, e as ações são realizadas com segurança [...] Aqueles para quem a moralidade é central nas suas identidades pessoais devem ser mais fortemente motivados por suas convicções e objetivos. (I993, p. I5I)

As observações desses psicólogos americanos vão ao encontro de umas das teses centrais da obra de Charles Taylor (1998), segundo a qual "o eu e o Bem, ou seja, o eu e a moral, se interpenetram de forma inextricável" (p. I 5).

Nosso objetivo será o de verificar se nossos sujeitos associam, de alguma forma, os valores morais que defendem à suas identidades. Se a reposta for positiva, teremos que tais valores devem traduzir uma força motivacional importante para as suas ações e, por conseguinte, que ações educacionais, para que assumam valores outros, deverão contemplar essa dimensão identitária.

\section{MÉTODO}

Participaram deste estudo 14 adolescentes autores de ato infracional, do sexo masculino, com idades entre 16 e 18 anos, internos na Febem/SP. $\bigcirc$ tema em torno do qual foram realizadas as entrevistas foi o do Seguro. Como assinalado, o Seguro é uma forma de exclusão de certos internos, promovida pelos próprios jovens. Em linhas gerais, torna-se 'seguro' quem não obedece a um conjunto de regras de comportamento dentro da Febem e também quem infringiu outras, valorizadas fora da instituição (como o fato de ter cometido estupro, por exemplo, ou de ter denunciado colegas). Os jovens no Seguro, além de excluídos, costumam ser vítimas de várias formas de violência, que podem ir até o assassinato, notadamente quando das rebeliões. Nosso objetivo foi o de fazer falar os jovens a respeito dessa prática denominada Seguro. Para tanto, foram realizadas entrevistas semidirigidas, com cada um dos adolescentes, em salas fechadas, nas unidades de internação. Cada entrevista foi gravada e transcrita para análise posterior.

Para as entrevistas, foi seguido um roteiro-base, que tinha como finalidade: I. obter uma descrição do Seguro, 2. avaliar a implicação pessoal do adolescente perante as regras por eles valorizadas; e 3. conhecer o juízo do adolescente para com essas regras. 


\begin{tabular}{|l|}
\hline \multicolumn{1}{|c|}{ ROTEIRO DA ENTREVISTA } \\
\hline I. Gostaria que você me explicasse/contasse/dissesse o que é o Seguro. \\
2. O que uma pessoa precisa fazer para ir para o Seguro? \\
3. Quais são as regras? \\
4. As regras são sempre as mesmas? \\
5. Quem pode mudá-las? Como se faz para mudá-las? \\
6. Quem as criou? \\
7. Quem está no Seguro sai dele? \\
8. Quando você chegou na Febem, já sabia essas regras? Como aprendeu? \\
9. Você já desrespeitou alguma dessas regras? Se sim, como foi? E você é do Seguro? \\
10.Você já viu alguém desrespeitando? Qual foi a regra? O que você fez? \\
II.Se você visse alguém desrespeitando alguma dessas regras, o que faria? \\
12.Você concorda com todas as regras? \\
13. Alguma regra dá para deixar passar? \\
14. O que você acha de um menino que está no Seguro?
\end{tabular}

Na apresentação dos dados, não destacaremos cada jovem entrevistado. Colocaremos, portanto, trechos de suas respostas sem a identificação do sujeito. Acrescentamos que não apresentaremos todas as respostas dadas a todos os itens do roteiro, mas apenas aquelas relacionadas às categorias de análise descritas: heteronomia/autonomia, virtudes e personalidade moral.

\section{DADOS E ANÁLISES}

\section{Heteronomia}

Comecemos pela questão da heteronomia/autonomia. A primeira coisa que chama a atenção é o grande número de regras que devem ser respeitadas pelos jovens. As formas de transgressão a elas são divididas em 'pé grave' (faltas graves) e 'banais' (faltas menos graves). Todavia, o desrespeito a qualquer uma delas é passível de ser sancionado pela ida ao Seguro. Como eles dizem, o transgressor pode tornar-se 'seguro'. 
Universo moral...

Antes de analisá-las do ponto de vista da autonomia/heteronomia, vamos arrolar as regras que os sujeitos nos relataram. Algumas delas dizem respeito a comportamentos anteriores à internação, com grande destaque para a proibição absoluta da delação e do estupro. A maioria diz respeito ao convívio na instituição. Várias são as regras de cunho claramente moral: não roubar pares, não delatar, não agredir gratuitamente, não mentir, não insultar (principalmente em relação à mãe de outrem), não fazer referências de ordem sexual à mãe dos colegas, não dever dinheiro. Ainda, no campo moral, há regras relativas ao trato das visitas que os internos recebem: não olhar as visitas femininas 'como mulheres', não mostrar o peito desnudo, não colocar a mão dentro da calça, não se masturbar em dia de visita. Como se vê, em relação a familiares, itens de uma moral sexual são, para os jovens, importantes, e a obediência à regra deve ser estrita. Note-se também o lugar de destaque que ocupa a figura da mãe: é figura sagrada. Voltaremos ao sagrado mais adiante.

Finalmente, há regras que poderíamos chamar de convencionais (Turiel, 1993), pois não remetem claramente a temas consagrados da moral. Tais regras regulam aspectos do convívio: ter higiene, não soltar flatos, somente se masturbar no banheiro (nunca na cama), não entrar sem camisa no refeitório e, nele, fazer silêncio, não impedir o sono dos colegas etc. Interessante notar que algumas dessas regras podem ser interpretadas como visando à preservação da privacidade alheia. De qualquer forma, é claro que as regras 'pé grave' e as 'banais' têm como função importante organizar o convívio e permitir a coesão do grupo - coesão esta que lhes permite sobreviver na instituição e enfrentar os agentes institucionais, quando for o caso.

Isto posto, empreguemos as categorias que definem heteronomia e autonomia para analisar as representações que os sujeitos têm das regras. Comecemos pela produção e legitimação das regras, sobretudo aquelas de cunho convencional, mais dificilmente atribuíveis a influências externas ao convívio grupal. Como elas são eleitas pelo grupo, poder-se-ia pensar em relações de cooperação, notadamente porque ficamos sabendo pelos nossos sujeitos que "O Seguro, o Sistema, é assim, cada unidade tem o seu sistema".

E, com efeito, alguns aspectos coerentes com a cooperação aparecem. Um sujeito fala em união: "Tudo aqui é sossegado, nós aceita a idéia do outro e é união". Outro fala sobre o objetivo comunitário de trabalhos que realizam: "A gente faz esse trampo pra ajudar a gente mesmo. Uma parte é para melho- 
rar a casa". Há falas nas quais a discordância a determinadas regras é aceita: "Se você não gosta da regra, a única coisa que você pode fazer é conversar sobre ela [...] Se tiver muitos que não gostam da regra e se unirem a você, vocês podem conversar". Palavras como democracia e debate, que, a priori, lembrariam processos de cooperação, também são empregadas. Todavia, assim como são pouquíssimos os exemplos de fala que remetem a um trabalho conjunto de elaboração e legitimação de regras e atividades, os conceitos de democracia e debate também não remetem à cooperação. Vejamos a única fala na qual a democracia é evocada:

Daí, normalmente, depois que tomou um "se liga malandro", os moleque geralmente concorda com a idéia. Mas se não concordar, aí é um couro, malandro. Mas é porque você tá indo contra o crime, contra seus amigos [...] Não é uma ditadura. Aqui isso é chamado de democracia, isso daí. Se você tá fazendo uma coisa errada e atrasando a casa toda, o que custa você mudar sua mente? Você é homem, pode mudar sua mente pra fazer uma coisa melhor pra você mesmo e pra casa toda.

Nota-se nessa fala que se trata muito mais de aceitar a regra vigente do que de participar de sua legitimação. Trata-se de obedecer. Outra fala é coerente com a anterior:

Aí, todo sábado a gente faz uma reunião sobre isso. A gente vê se o que a gente falou tá caminhando do jeito que a gente quer, o jeito que é pra casa melhorar. [...] Não tem votação. Aqui, nós pensa assim: se você é bandido, você corre pelo crime. Não tem como você correr contra o crime. Se a gente tá colocando uma melhora, pra casa e pra nós mesmos, e você não tá querendo concordar, você não tá correndo com o crime. Você tá querendo correr contra nós. Aí tem a conseqüência. [...] Não ocorreu ainda, mas tem de moleque tomar couro.

Verifica-se que se trata de cada indivíduo dobrar-se perante as vontades do grupo e não de coordenação de pontos de vista. Obedece-se a regras associadas ao 'mundo do crime' (voltaremos a essa noção quando falarmos de personalidade moral) e paga-se com a ida ao Seguro sua transgressão. E quanto ao 'debate', não se trata, como a palavra pareceria indicar, de uma reunião 
Universo moral...

de troca de idéias, mas sim de um verdadeiro tribunal no qual um presumido transgressor será julgado: "Ah, é um debate. Por exemplo, vamos dizer assim, um julgamento. Por exemplo, a pessoa fez alguma coisa errada, aí você tá debatendo, sabe. 'Ah, você fez isso, isso, isso de errado'. É depois do debate que a pessoa vira 'seguro'".

Em suma, observam-se relações de poder (o transgressor é coagido moral e fisicamente) e também de heteronomia: a regra é legitimada sem adesão intelectual a ela. A seguir, exemplos dessa heteronomia, ficando claro que os recémchegados recebem as regras prontas, sejam elas morais ou convencionais:

Tipo assim, eles [os recém-chegados] no pátio e aí nós passa assistência da casa para ele.

...no barraco, tem sempre um mais velho que ensina o moleque a se comportar na casa. ...Aí, você vai aprendendo; ele passa mais ou menos o essencial para você ficar direito e o resto você aprende no dia-a-dia.

E se, passado um tempo, o novato ainda não 'fica direito', o castigo é sumário: "Se ele vai e dá um pé uma primeira vez, se ele erra, passa até batido, os moleque não põem no Seguro nem nada. Mas se ele persistir de novo no erro, a segunda vez, fizer outro pé, aí ele vai para o Seguro". Em suma, tratase claramente de relações de coação, não de cooperação, fato sintetizado pelas duas seguintes falas: "Tem os mais velhos, que estão há mais tempo na casa, aí eles pensa como é aqueles mandamentos das antigas". O tempo e uma certa tradição explicam e legitimam as regras: "Quando eu cheguei já era assim. Todo lugar tem uma regra." Como não há nada escrito, a prática lembra o antigo direito costumeiro (ou direito consuetudinário), que se transmitia oralmente e era adaptado para cada momento histórico.

Poder-se-ia pensar que, no caso, estamos observando uma coação mais relacionada ao poder do que ao prestígio de alguma forma de autoridade. Ora, embora a coação pelo poder seja realidade entre os meninos da Febem (vamos vê-lo a seguir, quando falarmos de responsabilidade objetiva e sanções), o fato é que praticamente nunca nossos sujeitos colocam em dúvida a validade das regras. Dada a inteira liberdade para falarem e a absoluta garantia de sigilo, eles poderiam manifestar suas posições pessoais. Todavia, elas sempre vão na direção da explicitação da regra e de sua legitimidade. 
Não pode tirar a camisa em dia de visita. [...] Porque é falta de respeito. [...] Ah, tem várias coisas, senhora. É que nem... isso aí eles falam que é falta de respeito, senhora. Aqui, quando chega no dia da visita, assim, tem que por a camisa. Não pode, porque é falta de respeito. [...] Não sei explicar isso daí pra senhora.

Vê-se nesse depoimento a referência moral ao 'respeito', e a clara declaração heterônoma: 'não sei explicar'.

Outro aspecto que reforça a interpretação de traços de heteronomia no universo moral de nossos sujeitos é o império da regra sobre os princípios, império este que se traduz tanto pela falta de referência aos últimos como pela falta de real explicação da razão de ser das regras. Tal império é facilmente observado: praticamente em nenhuma fala há explicitação de princípios gerais dos quais seriam derivadas as regras, e tampouco explicações das razões de ser das regras. São freqüentes as falas como:

Se tiver certo, tá certo, se tiver errado, ele vai para o Seguro;

...não pode mostrar a cueca, sentar de perna aberta, usar sempre bermuda comprida, não usar camiseta com a gola larga pra não aparecer o peito;

...vai para o Seguro: se tirar castelo [masturbar-se];

Na hora de dormir, também, assim, como respeitar o sono do companheiro;

...entrar sem camisa no refeitório, entrar fumando no refeitório, não pode, tudo isso já é motivo pra ir pro Seguro.

Eis alguns exemplos de como são, nas entrevistas, apresentadas as regras, quase sempre no registro do dever negativo "não pode", e associadas a sanções inapeláveis quando da transgressão.

É interessante notar que, não raramente, a noção de "sagrado" é lembrada pelos jovens internos:

Quer ver, não pode um xingar a mãe do outro, sabe, tipo, de filha da xuxa. Não pode ficar falando palavrão muito, também. [...] Porque tem que ter um respeito. Se ficar, assim, xingando a mãe do outro, acho que nada vai prestar, não vai dar certo. Até porque, né, mãe, pra todo mundo, assim pra cada um é sagrada"; 
Universo moral...

A família tá lá fora, não tem nada a ver com aqui dentro. [...] Porque mãe é sagrado, né, senhora. Nem se eu tivesse lá fora, não gostaria que ninguém xingasse minha mãe, muito menos aqui dentro. Ninguém aqui gosta disso;

Daí, na hora de dormir, também, assim, você respeitar o sono do companheiro do lado. [...] Respeitar. Tipo, não ficar fazendo barulho, não incomodar o sono. Porque, tipo, geralmente, tem uma frase que, tipo, a gente fala que sono de malandro é sagrado;

Todo mundo deve rezar devagarzinho, com muita calma, você tá falando com Deus, é sagrado;

Pra cada um trocar idéia com seu barraco, para parar com essa patifaria, porque na copa, que é lugar sagrado.

As referências ao "sagrado" denotam o caráter moral das regras apresentadas, o fato de serem inquestionáveis. $O$ emprego da expressão 'sagrado' não implica automaticamente heteronomia, porém, como salientado por Durkheim e Piaget, em geral traduz um respeito unilateral, a aceitação incondicional de valores impostos por fontes de autoridade. Como o quadro que encontramos revela mais heteronomia que autonomia, faz todo sentido pensar que as referências ao sentimento do sagrado traduzam, elas também, tal heteronomia.

Outro traço típico da heteronomia é a responsabilidade objetiva, ou seja, aquela que se atém aos atos e não às intenções ou aspectos psicológicos que os inspiraram e/ou condicionaram. Ora, fica explícita a opção de nossos sujeitos por esse tipo de atribuição de responsabilidade. É claro que, em alguns casos, a não-referência à responsabilidade subjetiva advém do fato de nenhuma intenção poder justiçar certos atos. Tratando-se de estupro, por exemplo, não se vê bem que intenção poderia legitimar tal agressão, ou até mesmo, atenuar a culpa do agressor. Nossos sujeitos mostram-se categóricos a esse respeito:

Porque ele era estuprador lá fora. [...] Não pode. É uma coisa que é sem chance, assim, sabe, senhora. Sem perdão mesmo no crime, assim. [...] Ah, porque isso não é coisa que se faz, né? Assim, geralmente é porque, faz isso daí, vixe... Sei 
lá, até eu, assim, tipo, eu não sou, assim, sabe, a favor, assim, tipo, de pena de morte, sabe, de prisão perpétua nem nada. Mas em caso de estupro, assim, eu sou até a favor, senhora.

Encontramos outras falas desse tipo, que se atêm ao ato mesmo da violação sexual de mulheres. Outro exemplo para o qual pode-se conceber o predomínio moral da responsabilidade objetiva é o da delação; ouvimos sentenças como esta: "Geralmente, fica tudo jurado de morte: estuprador, cagüeta”. Delatar companheiros, assim como o estupro, não encontra justificativa possível, o que faz sentido.

Porém, não é apenas em casos de delação e estupro que verificamos o predomínio avassalador da responsabilidade objetiva, mas em todos os casos de transgressão a todas as regras. Uma primeira fala explicita esse fato: "Você está almoçando, supondo, e sem querer eu acabo soltando um peido, Nossa, daí é gravíssimo. Você vai acabar levando uma série de murros e acabar virando 'seguro'". Note-se aqui a clara referência ao 'sem querer'; mas, a sentença não o leva em conta: o castigo é inevitável. Vejamos outros exemplos. "olhou para aquela foto (de mulher, durante dia de visita), vai para o Seguro"; "Questão de visita então, fatal, se você desrespeitar a visita do cara, vai direto, não tem nem idéia"; "Você falar as coisas e não são, daí não dá. Depois que acontece, não tem como voltar atrás". Essa última fala coloca claramente o limite intransponível da responsabilidade objetiva: não tem como voltar atrás, não tem arrependimento.

Em algumas outras falas, há referência à possível intenção alheia, mas esta é sempre interpretada como negativa, como se a transgressão fosse necessariamente fruto de uma vontade criminosa. Por exemplo: "olhar para a visita dos outros, isto é morte, já. Eles pensam que a senhora está com maldade [...] Nossa, aquela mina lá é gostosa [...] isso já é maldade". Outro exemplo: "Eu ficasse olhando praquela mulher, não pode, eu to cobiçando ela".

Em suma, pouco e nenhum espaço há para a avaliação ponderada da intenção: o ato é o limite do juízo. Essa lógica condiciona as relações entre os jovens, como bem o expressa um sujeito: "Por isso, você tem que ser rígido. Porque os outros vão ser rígidos também com você". Outra fala resume tudo: "O crime é podre e não admite falhas".

Tal rigidez nos leva ao último item da oposição entre autonomia e hete- 
Universo moral..

ronomia: a qualidade das sanções. Piaget cunhou o conceito de "sanção por reciprocidade" para designar as punições que visam explicitar a quebra da relação de confiança e, assim, permitir ao transgressor redimir-se restabelecendo a reciprocidade assim por ele comprometida. Esse tipo de sanção, que pressupõe respeito mútuo, opõe-se àquelas chamadas de expiatórias, cuja finalidade é causar algum tipo de dor moral e/ou física ao culpado. Ora, uma vez que o Seguro traduz uma forma de exclusão do indivíduo em relação ao grupo, poder-se-ia pensar que é uma forma de tradução de sanção por reciprocidade. Nada, todavia, confirma essa hipótese: não costuma haver 'volta' ao convívio (como vimos, as pessoas excluídas 'tornam-se seguro', como se fosse uma nova e definitiva identidade) e os jovens excluídos são submetidos constantemente a castigos físicos. Os exemplos dados a respeito da responsabilidade objetiva dão clara idéia do fenômeno: fala-se em 'murros' e condenação à morte. Alguns outros exemplos confirmam essa valorização das sanções expiatórias:

...se o cara está devendo, tem que matar, se o cara deu um prazo e não pagou, tem que matar;

Foi quando me pegaram. Quebraram minha costela, tudo, me machucaram. Normal. [...] Isso aí com o tempo, você se acostuma, entendeu?

Já vi moleque sofrendo, já, senhora. [...] Ah, assim, tinha um moleque lá, senhora, que eu não me lembro o que ele fez, porque ele era "seguro", tava no mesmo barraco que eu. Ele ia dormir apanhando, pegava o rodo e batia aqui, aqui, aqui (mostra as articulações dos braços e das pernas). Os caras deixavam ele de morto-vivo... [...] Morto-vivo você enrola o moleque numas dez mantas. Aí tem a jega. Na jega, não tinha, assim, concreto embaixo da jega. Aí, eles enfiavam o moleque lá embaixo e tampava com o colchão. [...] É. O moleque quase morria;

Aí, os que cair a gente deixa e vai pegando os outros, senhora. Porque sempre tem um que leva uma ferrada e já cai, já. Faz que caiu pra nós não bater mais. [...] É. Daí, deixa lá no chão que esse daí já era. Mas nós, nós não abraça. Nós quebra já.

Pensamos que esses exemplos são suficientes para mostrar que as sanções em nada se inspiram pelos ideais de reciprocidade. A idéia de confiança 
mútua pouco trânsito tem, como bem o expressa um sujeito: "Aqui dentro, a confiança é complicada. Totalmente complicada". É por essa razão que imperam as sanções expiatórias e a forma de responsabilidade que lhe é costumeiramente associada, a responsabilidade objetiva.

Em resumo, o universo de valores morais dos jovens pesquisados revela muito mais elementos relacionados à heteronomia do que à autonomia. No entanto, há entre esses jovens uma dimensão moral que não se relaciona diretamente com o binômio autonomia/heteronomia, mas sim com a valorização das virtudes.

\section{Virtudes}

Se nossos sujeitos pouco levam em conta a intencionalidade dos atos, em compensação, estão muito atentos ao caráter das pessoas que os cometem, assim como ao caráter de todos os membros do grupo. Eles também se remetem a virtudes, mas antes vejamos como avaliam e exigem certas características de caráter.

Quando um novo membro adentra a Febem, ele é submetido a uma espécie de teste por parte de seus pares, que eles chamam de 'batizado'. Tal teste é também e curiosamente - sabiamente talvez - denominado pela expressão 'dar um psicológico'. Um exemplo de fala na qual comparece essa referência: "Primeiro, vão te testar, te dar um psicológico pra ver se você é uma cara consciente, não é boca-aberta, nem nada, ou se tem algum problema". Tal 'dar um psicológico' é assim descrito em outra fala:

Lá, quando você chegava, tinha o chamado comitê de recepção, pra ver se você se garantia lá dentro ou não. [...] [Recepção] De bater. Psicológico e de bater. [...] Eles pegam ali com as naifa, ali com as facas, vem em cima de você, 15, 20, e começa a pressionar. Perguntar se você é Jackie, estrupador [sic], porque não pode. [...] E se o menor tivesse a cabeça forte e agüentasse o psicológico deles, agüentasse as pancada, ainda assim ainda tava bom. Agora, tinha uns ali que chegava até a cagüetar, chegava até a falar pros funcionário. Não chegava a virar "seguro", porque os menor parava de bater, mas mesmo assim acabava fazendo trabalho pros cara, ficava no pátio, mas não é convívio deles. Sempre teve esse problema. Então, logo que você chega, tem que apanhar. 
Universo moral...

Como se verifica, a função da administração do 'psicológico' é testar o caráter do recém-chegado, é avaliar sua firmeza, sua capacidade de agüentar a inquisição, de se mostrar coerente: "Como tem eu e uns mais velhos na casa, entramos na mente dele. [...] Nós vai conversando, trocando uma idéia, tipo jogando uma idéia nele, porque vai fazendo ele se condenar com as palavras dele. [...] Cair em contradição". Outro exemplo: "Lógico que é, é minha palavra. Não pode voltar atrás, senhora". Não parece se tratar de uma avaliação a respeito da verdade ou falsidade do que é respondido pelo indivíduo interrogado, mas da sua capacidade de manter-se firme e forte perante os questionamentos. É o que transparece da seguinte fala: "Aquele que gaguejar, já era, senhora. [...] Mesmo que ele esteja, senhora. Se ele cair em contradição ou gaguejar". Note-se a referência ao 'mesmo que ele esteja certo'. Poderíamos dizer que a força de caráter é valorizada, e não se deixar intimidar é prova dessa força. $\bigcirc$ 'fraco' não tem lugar no grupo não somente porque não tem firmeza, mas também porque ele não é 'homem'.

Com efeito, exemplos de fraqueza associados à falta de virilidade são dados pelos jovens para desqualificar certas pessoas. Vamos começar com uma das razões pelas quais o estuprador é radicalmente banido:

Por causa que é uma coisa que, sei lá, eu não admito, não, senhora. Principalmente hoje em dia, qualquer lugar que você vai, assim, tem lugar que até 10 reais você paga e sai com uma mulher para passar a noite. $\bigcirc$ cara vai estuprar criança, senhora de idade... às vezes até espanca, tudo, isso é uma coisa que, sei lá, não tem lógica pro cara fazer. O cara querer abusar de uma mulher. [...] Então, porque... sei lá.... um até porque, tipo, eu acho que ele já é um fracassado, porque ele... porque assim, sei lá, por ele não ter uma competência prá, tipo, sei lá, atrair uma mulher, seduzir uma mulher, sabe... prá namorar, prá sair, prá ficar junto.

O estuprador, além de infringir uma regra 'sagrada', é visto como um homem fracassado, um incompetente. Outro tipo de personagem a quem se atribui fraqueza é o homossexual, que é chamado de 'desandão': "Desandão uma vez, desandão sempre. É o pior, pilantra. Você é louco? Como é que um homem, um cara que se julga homem, eu falo assim, se julga, porque pra mim não é homem, vai dando ré...". 
Se o 'fraco' é radicalmente desvalorizado, o forte, além das características de firmeza e coerência que já destacamos, é alguém que faz emprego da força física. Referindo-se a características de líder, um sujeito assim se expressa: "Ele matou delegado, matou polícia, acho que ele já matou um montão de gente, senhora. [...] Por isso ele é considerado. [...] Ah, os outros considera ele, senhora. Falam 'ah, o cara é perigoso, senhora, e tal, tudo'. [...] É. Os cara acha isso dele".

Embora eles não tenham empregado a palavra 'coragem', virtude moral tão conhecida quanto polêmica (ver Comte-Sponville, 1995), tal traço de caráter parece ser extremamente valorizado e traduzido tanto pela capacidade de mostrar-se firme perante pressões morais e físicas, quando pelo recurso do uso da força. Eis o que fazem, por exemplo, com o fraco que não agüenta pancada: "Aí, os que cair a gente deixa e vai pegando os outros, senhora. Porque sempre tem um que leva uma ferrada e já cai, já. Faz que caiu prá nós não bater mais. [...] É. Daí, deixa lá no chão que esse daí já era. Mas nós, nós não abraça. Nós quebra já". E eis a postura valorizada: "Porque eu nunca fui de pegar e ir pra cima de adolescente, eu tive atitude de homem. Se eu tiver que bater, eu vou bater sozinho. Se tiver que apanhar, vou apanhar sozinho".

Outro traço de caráter que remete a virtudes outras que não a virilidade é a força de assumir os erros, traço também associado ao 'ser homem'. Exemplos: "Tipo ele avistou a família do outro menor lá, senhora. E não podia. Aí ele foi, foi sujeito homem e assumiu o que ele fez"; "Aí os caras falou assim: 'é, você já é bandido, porque você já assumiu seu erro".

Voltaremos ao item 'personalidade moral' a essa importante referência a 'ser bandido'. Os jovens falam também em dignidade:

Uma pessoa digna é o seguinte, vamos supor, se é um futebol, um basquete, um pingue-pongue, um vôlei, qualquer coisa que tiver você vai se envolver aqui dentro. Se faz as coisas errado, assim, você vai ficar destacado. Esse maluco que não é digno, não vai ter como, porque, se a senhora quiser colar: "você não é digno de colar com nós, mano. Destaca”. Tá ciente? Aí, vai destacar, senhora. Ele não é digno. Pra nós, é que não pode conviver com nós.

Como se vê, não se trata da dignidade no sentido de um atributo inerente ao ser humano, tampouco de um direito moral (ter a sua dignidade re- 
Universo moral...

conhecida): trata-se de um adjetivo que qualifica aquele que merece conviver com os demais e que, para isso, se comporta conforme as regras. Não deixa de ser um traço de caráter, uma vez que se remete ao 'ser'. $O$ 'não digno' vai para o Seguro, lugar no qual se encontram as pessoas que não despertam forma alguma de respeito ou admiração: "Seguro é menos", diz um sujeito. Aliás, não raramente ouvimos palavras como 'safado', 'pilantra', 'maluco', e outras forma de insultos que, justamente, remetem não a ações isoladas, mas à índole suposta de quem as realiza.

Finalizamos trazendo mais duas virtudes que, diferentemente das que comentamos até aqui (virilidade, coragem, firmeza, lealdade), não apresentam caráter moral. A primeira delas é a humildade. Poder-se-ia pensar que se trata, também nesse caso, de virtude moral, uma vez que a humildade não raramente, principalmente na religião cristã, é altamente valorizada como característica da boa pessoa e como oposta a vícios, como o orgulho e a vaidade. Todavia, as falas levam a crer que não se trata desta interpretação moral da humildade, mas de uma avaliação pragmática de seu valor para evitar conflitos. Eis uma fala que se remete à humildade: "Você tem que ser humilde, assim, entre aspas também... Você tem que regularizar também a humildade. Senão... Você tem que regularizar, sabe". Eis outra que explicita o sentido da anterior:

Tem que falar assim: "eu falo por minha pessoa, não falo por todo mundo, eu acho que isso aqui podia ter conversa”. [...] Se a senhora chegar na educação, no respeito, assim, não acontece nada. Se a senhora chegar: "ah, vai ter que conversar no refeitório, nós vai conversar no refeitório”, aí, já era. [...] Aí, é só facada, senhora. Aí, os cara vai chegar e falar assim: você pensa que você manda em alguma coisa aqui dentro?

Trata-se de não se mostrar superior aos outros, não procurar 'ibope', como eles dizem, de não querer ser o 'mandão'. A falta de humildade, no sentido por eles empregado, é, como tudo que se relaciona a regras e caráter, passível de sanção: "Vamos supor, ele queria ganhar ibope, queria ser mais que os outros. Já que eu fiz isso, eu sou melhor que você [...]. Só que até então ele se enganou, porque não é bem assim. Aí, entramos na mente dele, ele falou que era tudo mentira, foi pro Seguro". 
A humildade remete a uma outra virtude, racional como queria Aristóteles, que é a "prudência". Para sobreviver na Febem, é preciso tomar extremo cuidado com o que se diz, com as ações e também, como vimos, com os traços de caráter que se deve mostrar. É o que passam aos recém-chegados:

Aí é que o moleque é primário, tinha que fortalecer a mente dele, dar uma idéia para ele ficar firmão, pra não ocorrer mais isso. [...] Ficar firmão é tipo você seguir o ritmo da cadeia e correr com os cara. Correr assim, ficar com os cara, fazer mais nada, seguir o ritmo. Vamos supor, seguir o ritmo.

Outra fala resume bem a necessidade de prudência: "Você já tem que chegar bem mansinho, bem na moral, de boa, senhora". Lembremos a fala citada: "Aqui dentro, a confiança é complicada. Totalmente complicado". Prudência e humildade não são luxos, mas virtudes incontornáveis, como também o são mostrar-se firme, viril e violento. Mas há outra condição hipervalorizada: ser do 'mundo do crime'.

\section{Personalidade moral}

Os traços de caráter descritos pelos nossos sujeitos remetem, é claro, ao "eu", portanto às representações que eles fazem e valorizam deles mesmos. Trata-se de uma construção identitária. Mas há um outro elemento nessa construção, que não remete a virtudes, mas, sim, ao pertencimento a um determinado grupo social. Estamos falando do 'mundo do crime', cujos membros são chamados, pelos próprios sujeitos, de 'bandidos' e 'malandros'. Lembrando algumas falas nas quais tais referências comparecem,

O crime é podre, mas não admite falhas.

... se você é bandido, você corre pelo crime. Não tem como você correr contra o crime.

Aí os caras falou assim: "é, você já é bandido, porque você já assumiu seu erro... O moleque é sem palavras, o moleque é bandido, não dá pé pra ninguém, não caça assunto com ninguém, faz o trampo dele de boa, acho que não tem motivo pra ele estar no Seguro". 
Universo moral...

Note-se que, entre as perguntas que dirigiram as entrevistas sobre o Seguro, nenhuma incidia sobre traços identitários. As referências ao 'mundo do crime' foram, portanto, feitas espontaneamente, decerto porque representam aspecto importante das avaliações que fazem das regras que criam e às quais se submetem. E é verossímil pensar que o valor maior que legitima as regras e os traços de caráter é a referência a uma determinada comunidade que os jovens identificam ao crime. Eles mostram ter orgulho de pertencer a tal mundo e de se verem como bandidos ou malandros. 'Sono de malandro é sagrado', como nos disse um deles, levando a crer que, para ele, ser 'malandro' não é uma condição qualquer, mas sinal de status. Aliás, talvez seja por essa razão que não ouvimos dos nossos sujeitos queixas, discursos sobre vitimização que eles estariam sofrendo. Certamente não faltariam motivos para queixas, para se verem como vítimas da sociedade, mas, não, preferem ver a si mesmos como membros de uma "outra" sociedade.

Com efeito, não raras são as referências ao referido 'mundo do crime' em oposição ao resto da sociedade. "Tem algumas coisas, assim, sabe, que pro mundo do Crime é certo, sabe, mas pro outro mundo, honesto, não é”. Citamos agora falas que opõem os membros desse mundo aos outros, começando pela referência aos 'pilantras': "Bandido é bandido, pilantra é pilantra. Não tem essa de ser mais, nem nada. Todo mundo é bandido, sabe?". Um dos terríveis castigos que representa a ida ao 'Seguro' é justamente a supressão da identidade de 'bandido': "Pra eles, bandido é quem tá no convívio. Pilantra é Seguro. Pilantra não é mais bandido. Assim que eles falam". Outro exemplo: "Fala que esse cara é do seguro, safado, pilantra”. Quem está no 'Seguro' "é tipo a menos". Mais ainda: para ser do 'mundo do crime' é preciso realmente valorizá-lo e não estar nele por motivos fúteis, como o de 'aparecer':

Se o cara tiver uma idéia pra queimar, tá firmão. Tem que ter um argumento. Porque se é alguém bobinho, que tá no crime só por emoção... E tem muitos aqui... Tem uma pá de moleque aqui que gosta de ser ladrão, quer pagar de bandido. Mas esses moleque que é tipo boyzinho, tá no crime só pelo ibope... ibope das mina na rua, dá mesmo. [...] Só pelo ibope, só. Não tem nem precisão de nada. 
A oposição da comunidade à qual se identificam em relação aos outros membros da sociedade também se expressa pela linguagem:

É a linguagem que nós tem, que é diferente do mundão. Porque no mundão nós fala peito, boca, cabeça. E aqui, Febem, rola uma maldade, senhora. [...] Vamos supor, a senhora fala olho, só que aí nós vamo dar risada, senhora. Porque nosso ponto de vista, aqui é vista mesmo. A vista e tal, nariz, boca, e aí, cabeça já é pote, porque cabeça já tem outros negócio e tal. Aí nós fala pote.

Nas entrevistas tivemos a oportunidade de verificar o grande número de palavras diferentes que empregam. Citamos alguns exemplos cuja definição foi dada pelos próprios sujeitos:

Caneca: é um desandão; Cinco: seguro, não pode trocar com convívio; Coruja: é cueca, senhora; Descascar: É a mesma coisa de tirar castelo, bater punheta, esses bagulhos; Jogar massa: é mentir; Sangue bom: Todas as pessoas que não eram do Seguro, eles falam que é sangue bom.

Esta última expressão, 'sangue bom', sublinha a diferença positiva que separa os jovens do convívio dos outros, e todas elas juntas denotam a necessidade de criar um código próprio que eles mesmos sabem não ser compreendido pelas pessoas de fora do grupo, do 'mundão', como eles dizem.

Em resumo, tudo leva a crer que as práticas, as regras e as virtudes descritas e valorizadas pelos jovens internos da Febem são permeadas por um valor maior: ver a si próprio como membro de uma determinada sociedade que se opõe a outras, e ter orgulho disto. Trata-se de um "nós" (mundo do crime), que se opõe a um "eles" (mundão). E, como apontado por Lotman ( 198 I), perante os membros do "nós", sente-se vergonha quando não se corresponde às práticas e virtudes legitimadas pelo grupo. Em compensação, sente-se "medo" das pessoas que pertencem ao "eles", e se procura também inspirar medo a eles. Se, como assumido pelas teorias da "personalidade moral", ou "personalidade ética", as representações de si mais valorizadas são uma fonte energética de peso para a escolha das ações, temos que nossos sujeitos colocam no centro de suas representações de si o 'pertencer ao mundo do crime' 
Universo moral..

e que tal identificação os faz legitimar uma série de atitudes e virtudes que, para eles, parecem se revestir de um caráter moral: o 'malandro', para merecer esse nome, deve agir de determinados modos e possuir determinadas características de personalidade. Mas, se nossa hipótese for correta, de onde virá o apego a tais representações de si? Embora não seja o objetivo deste artigo responder à pergunta - resposta esta para a qual, aliás, não possuímos os dados necessários - vamos rapidamente comentá-la tecendo, à guisa de conclusão, algumas considerações educacionais.

\section{CONCLUSÕES}

intento de nossa pesquisa foi o de identificar alguns aspectos do universo moral de jovens internos da Febem, por intermédio dos juízos que fazem a respeito de uma prática de convívio criada por eles mesmos. Não se tratou, portanto, de avaliar o nível de juízo moral de nossos sujeitos, mas de verificar por intermédio de quais critérios eles legitimam sua própria prática.

Uma primeira característica que nos chamou a atenção é a corrente postura heterônoma em relação às regras legitimadas, postura esta sugerida pelo fato de haver freqüentes referências a fontes externas de legitimação, de haver o primado das regras sobre os princípios, de haver poucas explicações a respeito da razão de ser dessas regras, de a responsabilidade objetiva imporse em detrimento da responsabilidade subjetiva, e de as sanções serem predominantemente expiatórias. Se nosso diagnóstico for correto, certamente de nada adiantam as práticas pedagógicas disciplinares que a literatura afirma serem as prediletas daqueles que lidam com os jovens (Noguchi, 2006). Isso equivale a trocar uma forma de coação por outra e, logo, uma forma de heteronomia por outra. Aliás, os depoimentos que recebemos tendem a mostrar que não é a disciplina que falta aos jovens: eles têm variadas regras às quais se atêm de maneira estrita e cuja desobediência é severamente punida. Não parece faltar-Ihes disciplina, portanto. Mas tal disciplina incide sobre regras que eles mesmos instituíram. Ora, o que os educadores desejariam é que obedecessem a outras regras, as da instituição. Para tanto, há duas formas possíveis. Uma delas é pelo exercício da força: exigir obediência mediante ameaças de sanções. Essa opção tende, naturalmente, a perpetuar as relações de violência. A outra seria pelo exercício da autoridade, o que pressuporia que os jovens vissem, na 
figura dos educadores, pessoas imbuídas de alguma legitimidade para mandar. Porém, sabe-se, não é o caso. Ao contrário: não é no que chamam de 'mundão' que se encontram os valores dignos de serem respeitados (e os educadores fazem parte desse 'mundão'), mas sim no 'mundo do crime', com suas leis que possuem legitimidade aos olhos dos jovens. Em suma, parece-nos que uma prática disciplinar que realmente possa ter efeitos positivos é impossível. Seria necessário promover, de alguma forma, relações de cooperação, que parecem ser inéditas para esses jovens, e que lhes possibilitariam pelo menos intuir novas formas de relacionamento entre as pessoas. E se Piaget e Kohlberg tiverem razão, essas formas teriam, pela sofisticação intelectual que pressupõem, um apelo não desprezível, elas proporcionariam experiências gratificantes e seriam mais atrativas que as relações de coação.

Uma segunda característica que encontramos refere-se à valorização de traços de caráter, ou virtudes. Duas são pragmáticas e complementares: a humildade e a prudência. Delas depende, em parte, a sobrevivência no grupo. Outras são propriamente morais, pois correspondem a qualidades vistas como necessárias às pessoas dignas: firmeza, virilidade, força, coragem. Se traços de heteronomia podem ser vistos como fatores complicadores para a educação moral, o mesmo não pode ser dito a respeito da valorização das virtudes. Ao contrário até, uma vez que, como dito no início do texto, elas representam qualidades de caráter essenciais à ação moral. Como escreveu Comte-Sponville (1995), às vezes sabemos o que é justo fazer, mas não agimos por falta de generosidade ou falta de coragem. Ora, os jovens internos da Febem, ao mostrar que atribuem grande valor a traços como firmeza, coragem, coerência, colocam o educador em um terreno fértil para trabalhar temas morais. $\bigcirc$ trabalho deve incidir sobre o conteúdo associado a essas virtudes. De fato, com exceção da justiça, que é sempre boa, segundo pensava Aristóteles, o valor das demais é condicionado aos conteúdos a que se referem. Por exemplo, a coragem é, a priori, admirável, contudo, perde valor moral se associada à execução de atos violentos. É provavelmente necessário coragem para realizar assaltos a banco, mas nem por isso ela é, nesse caso, louvável. Mesma coisa pode-se dizer da firmeza: sem ela é difícil resolver, de forma assertiva, conflitos interpessoais, porém ela também pode levar a formas violentas de enfrentar a adversidade. Logo, um trabalho educativo com virtudes deve separar forma de conteúdo: firmeza, coragem, virilidade são qualidades apreciáveis, contanto 
Universo moral...

que não traduzidas pela violência e instrumentalização de outrem. Ora, vimos que tal violência está, para nossos sujeitos, associada às virtudes. Pode-se procurar com eles refletir sobre o valor dessa associação, e buscar outras.

Porém, a terceira característica que encontramos - a identificação com o 'ser malandro', com o 'pertencer ao mundo do crime', que parece ocupar lugar central nas representações que os jovens fazem e valorizam de si - certamente é um fator complicador de qualquer empreitada educacional com jovens internos. $\bigcirc$ que se entende por medidas socioeducativas é um conjunto de práticas pedagógicas que visam à reintegração dos jovens na sociedade, portanto, naquilo que eles chamam de 'mundão' ou de 'outro mundo honesto'. Porém, esse mundo, como o vimos claramente, é considerado oposto ao deles, e a oposição está presente nas representações que fazem de si. Desse modo, como ter êxito na reintegração em um mundo visto como oposto ao deles e desprovido das qualidades que valorizam? Mais ainda: como reintegrálos a um mundo que, em grande parte, é responsável pelo fato de eles se identificarem com um outro? Falemos um pouco mais dessa questão.

Perguntamo-nos, no final da apresentação e análise dos dados, quais seriam as razões dessa identificação com o chamado 'mundo do crime'. Há certamente inúmeras variáveis em jogo, entre as quais a influência do meio em que nascem e vivem. Mas há certamente outra, de peso: o desprezo nutrido pelas outras classes sociais em relação a eles. Sabe-se que, não raramente, eles ouvem de seus professores de escola que de nada adianta educá-los, pois tornar-se-ão necessariamente "marginais". Uma pesquisa realizada com os chamados "meninos de rua" (La Taille, 200I) - na verdade, meninos que passam bastante tempo nas ruas, longe de suas famílias, mas que raramente têm nas ruas sua única moradia - mostrou o quanto se sentem desprezados e humiIhados pelos diversos transeuntes. É com dor psíquica que observam janelas de carros se fecharem quando chegam, que percebem os desvios que as pessoas fazem para não se aproximar deles, que notam expressões de antipatia nos olhares a eles dirigidos. Vimos nas falas de nossos sujeitos que eles dividem a sociedade em "nós" e "eles", e que esse "eles" refere-se às pessoas de um 'outro mundo, honesto'. Mas deve-se convir que tal oposição também é feita pelos membros desse 'mundão'. Não se trata, para os jovens da Febem, de uma vontade misteriosa e gratuita de se diferenciar das outras pessoas, mas, sim, de uma das conseqüências de sua exclusão. $\bigcirc$ que sobra para construir representações positivas de si senão escolher outras que as valorizadas pela 
sociedade em geral? Senão até, escolher aquelas que se opõem aos olhares de desprezo e humilhação. Perguntado de outra forma: como existir aos olhos da sociedade senão dando valor àquilo mesmo que os exclui dela?

Voltando à pesquisa com os "meninos de rua", alguns relatos mostram que eles percebem que, embora desprezados pelas pessoas que cruzam, eles têm alta visibilidade para elas, e isto em razão do medo que eles notam nelas despertar. Logo, eles verificam que existir aos olhos alheios não depende do respeito moral que lhes é devido, mas do medo que inspiram aos outros. Como a visibilidade social, portanto o "existir" no mundo é condição psicológica necessária à sobrevivência psíquica, compreende-se bem que idealizem o 'mundo do crime', esse mundo temido pela sociedade. Conforme Soares, Bill e Atayde: "Há uma fome mais profunda que a fome física, mais exigente que a fome física: a fome de sentido e de valor; de reconhecimento e acolhimento fome de ser - sabendo-se que só se alcança ser alguém pela mediação do olhar alheio que nos reconhece e valoriza" (2005, p.2 I5). Parece ser identificandose ao que chamam 'mundo do crime' que conseguem, ou pensam conseguir, tal sentido e valor. $\bigcirc$ 'mundão' os priva dessa possibilidade. Como também escrevem os mesmos autores: "Esmagando a auto-estima do adolescente que errou, a sociedade lava as mãos, mais ou menos consciente de que está armando uma bomba-relógio contra si mesma" (p.219).

É bem provável que o que se faz na Febem com esses jovens nada mais seja que aumentar o poder dessa "bomba-relógio". É, pelo menos, o que as práticas a ela atribuídas levam a crer (Noguchi, 2007). Mas não sejamos injustos: há trabalhos diferenciados sendo feitos por algumas pessoas na Febem, como, por exemplo, o de Valéria Di Pietro, que montou, com sucesso, uma peça de teatro (Num lugar de la Mancha) com meninos internos, o que thes permitiu um belo trabalho de reflexão e, também, obter o reconhecimento alheio (a peça foi apresentada, entre outros lugares, no Tuca Arena, em 2005). Porém, mesmo que se multipliquem tais iniciativas, mesmo que se mudem radicalmente as práticas dessa instituição, não poderá caber somente a ela desativar a "bomba". Uma dimensão social mais ampla está em jogo. Não é apenas de pedagogia e didática que se trata, mas sim de um rearranjo ideológico, ético e político de toda a sociedade. 
Universo moral..

\section{REFERÊNCIAS BIBLIOGRÁFICAS}

ARISTOTE. Ethique à Nicomaque. Paris: Flamarion, 1965.

AUN, H., A. Trágico avesso do mundo: narrativas de uma prática psicológica numa instituição de jovens infratores. São Paulo, 2005. Dissert. (mestr.) Instituto de Psicologia da Universidade de São Paulo.

BENNET, W. J. O Livro das virtudes. Rio de Janeiro: Nova Fronteira, 1995.

BLASI, A Moral understanding and the moral personality: the process of moral integration. In: KURTINES, W. M. (org.) Moral development: an introduction. London: Allyn and Bacon, 1995. p.229-254.

COLBY, A.; DAMON, W. The Uniting of self and morality in the development of extraordinary moral commitment. In: NOAM, G. G.; WREN, E. (org.) The Moral self. Cambridge: The Mit Press, 1993. p.|49-174

COMTE-SPONVILLE, A. Petit traité des grandes vertus. Paris: PUF, 1995.

DURKHEIM, E. L'Education morale. Paris: PUF, 1974.

EISENBERG, N. Developpment of chidren's prosocial judgment. Developmental psychology, v.2, n. 15, p.129-137, 1979.

EISENBERG, N.; MILLER, P. A. The Relationship of empathy to prosocial and related behaviors. Psychological Bulletin, n. I01, p.91-119, 1987.

FLANAGAN, O. Psychologie morale et éthique. Paris: PUF, 1996.

GILLIGAN. C. Uma voz diferente. Rio de Janeiro: Rosa dos Ventos, 1982.

HOFFMAN, M. Desenvolvimento moral. In: CARMICHAEL, A. (org.) Psicologia da criança, socialização, 2. São Paulo: Edusp, | 978. p. I- 170.

KANT, E. Métaphysique des moeurs: première partie. Paris: Flamarion, 1994.

KOHLBERG, L. Essays on moral development. San Francisco: Harper \& Row, 1981.

LA TAILLE, Y. de. Honte e morale. In: COLLOQUE CONSTRUTIVISME: USAGES ET PERSPECTIVES EN EDUCATION. Anales... Genève: Archives Jean Piaget, 200 I. (CDROM).

A Importância da generosidade no início da gênese da moralidade na criança.

Psicologia, Reflexão e Crítica, v. 19, n. I, p. 9-17, 2006.

Moral e ética: dimensões intelectuais e afetivas. Porto Alegre: Artmed, 2006a. 
Para um estudo psicológico das virtudes morais. Educação e Pesquisa, São Paulo, Faculdade de Educação/USP, v.2, n.26, p. 109-122, 2000.

LOTMAN, J. M. Semiótica dos conceitos de vergonha e medo. In: LORMANM, L. M. et al. (org.) Ensaios de semiótica soviética. Lisboa: Horizonte, 1981. p.237-240.

MACINTYRE, A. After vertue: a study in moral theorie. London: University of Notre Dame Press, 1981.

MILGRAM, S. Soumission à l'autorité. Paris: Calam-Levy, 1974.

NOGUCHI, N. F. de C. Seguro na FEBEM-SP: universo moral e relações de poder entre adolescentes internos. São Paulo, 2006. Dissert. (mestr.) Instituto de Psicologia da Universidade de São Paulo.

PIAGET, J. Études sociologiques. Paris: Droz, 1977. Le Jugement moral chez l'enfant. Paris: PUF, 1992.

PUIG, J. M. R. A Construção da personalidade moral. São Paulo: Ática, 1998.

SARTI, C. A. Aberturas e impasses na reestruturação da Febem. In: CENTRO DE ESTUDOS E PESQUISAS EM EDUCAÇÃO, CULTURA E AÇÃO COMUNITÁRIA. Educação e cidadania: proposta pedagógica. São Paulo: Cenpec, Febem; SEE/SP, 2004. p. I 5-2I. (Col. Educação e Cidadania)

SOARES, L. E.; BILL, M. V.; ATAYDE, C. Cabeça de porco. Rio de Janeiro: Objetiva, 2005.

TAYLOR, C. Les Sources du moi. Paris: Seuil, 1998.

TEIXEIRA, M. L. T. Adolescência e violência: uma ferida de nosso tempo. São Paulo, 2002. Tese (dout.) Faculdade de Serviço Social, Pontifícia Universidade Católica de São Paulo.

TUGENDHAT. E. Conférences sur l'éthique. Paris: PUF, 1998.

TURIEL, E. The Development of social knowledge: morality and convention. Cambridge: Cambridge University Press, 1993.

VICENTIN, O. V. A Vida em rebelião: jovens em conflito com a lei. São Paulo: Hucitec, Fapesp, 2005.

Recebido em: novembro 2006

Aprovado para publicação em: julho 2007 